\title{
TIPOLOGI DAN KUALITAS PENGGUNAAN RUANG PUBLIK PERMUKIMAN KAMPUNG KOTA MALANG
}

\author{
Wulan Dwi Purnamasari, Oktavia Indah Rudinanda, I Nyoman Suluh Wijaya, \\ Jurusan Perencanaan Wilayah dan Kota Fakultas Teknik Universitas Brawijaya \\ Jalan Mayjen Haryono 167 Malang 65145 -Telp (0341)567886 \\ email:wulanralando@gmail.com
}

\begin{abstract}
ABSTRAK
Kampung kota adalah kelompok perumahan yang merupakan bagian kota dengan kepadatan tinggi dan mengandung arti perumahan yg dibangun secara tidak formal. Penyediaan ruang interaksi sosial masyarakat permukiman kampung berupa ruang publik sebagai sebuah keharusan menjadi sulit terlaksana. Ruang "ambigu” dengan fungsi ganda pun bermunculan seperti jalan untuk ruang bermain, teras untuk ruang interaksi, dst. Oleh karena itu, penelitian ini bertujuan melihat kualitas ruang publik yang terdapat di permukiman kampung baik pusat dan pinggiran kota dan bagaimana persepsi pengguna terhadap kualitas ruang tersebut. Metode peneltian ini berupa analisa penilaian kualitas ruang publik menggunakan Good Public Space Index (GPSI) dan persepsi pengguna ruang publik. Hasilnya menunjukkan bahwa sebagian besar ruang publik yang terdapat di kampung pusat dan pinggiran kota memiliki kualitas 'sangat baik' dan 'baik'. Pada penilaian berdasarkan persepsi pengguna ruang publik, terdapat ruang-ruang yang memiliki kualitas 'baik' tetapi memiliki beberapa indikator yang 'buruk' sehingga berpengaruh terhadap penilaian kualitas berdasarkan GPSI.
\end{abstract}

Kata Kunci : Kota Malang, Kampung Kota, Kualitas Ruang Publik, Good Public Space Index (GPSI)

\section{ABSTRACT}

Urban kampong is a housing group that has high population density and it is not formally constructed. Places for the community social interaction as an agreement in the form of public spaces becomes difficult. This research was conducted to see the quality of public space both in the central and suburban kampong settlements and how the user's perception of the quality. The method that used to assessed the quality of public space by using the Good Public Space Index (GPSI) and the perception of users of public spaces. The results shows that most of the public space in the central and suburban kampong has a 'very good' and 'good' quality. The assessment based on the perception of users of public space, there are spaces that have a 'good' quality but have several indicators that are 'bad', thus affecting the quality assessment based on GPSI.

Keywords: City of Malang, City Village, Quality of Public Space, Good Public Space Index (GPSI)

\section{PENDAHULUAN}

Sebagian besar wilayah kota-kota besar di Indonesia ditempati oleh pemukiman padat dan tidak terencana dinamakan kampung (Nursyahbani dan Pigawati, 2015). Ketersediaan lahan yang terbatas tidak sebanding dengan pertumbuhan populasi setiap tahunnya sehingga menciptakan ruang-ruang dengan kepadatan yang sangat tinggi di kawasan pusat kota, tetapi walaupun demikian tidak menutup kemungkinan pada kawasan pinggiran kota hal tersebut juga terjadi.

Ketersediaan lahan tersebut berpengaruh salah satunya pada keberadaan ruang publik Pemanfaatan lahan yang kurang maksimal sebagai wadah untuk aktivitas masyarakat akhirnya menyebabkan dwifungsi lahan di permukiman padat, salah satu contohnya adalah kegiatan bermain anak-anak yang harusnya dilakukan di ruang publik berupa taman atau lapangan tetapi dilakukan di jalan atau gang sempit (H. Fauzi, 2014). Ruang publik yang baik dapat dilihat dari tingkat pemanfaatan oleh masyarakat baik dari jenis aktivitas maupun jumlah pengguna ruang publik tersebut. Apabila sebuah ruang publik tidak mencerminkan hubungan antar individu di dalamnya maka ruang tersebut tidak berfungsi secara optimal (Siahaan, 2010). Ruang publik bukan hanya memberikan image pada kota, namun juga menghargai masyarakatnya yaitu dengan 'keterbukaan' ruang publik itu sendiri. Ruang Publik yang bersifat sosial dapat dinikmati semua orang tanpa batasan, sebagai tempat berkumpul dan mengakrabkan komunitas perkotaan (Prihutami, 2008).

Berdasarkan kondisi ruang publik yang ada saat ini, permukiman dapat membentuk sebuah ruang khusus yang dapat digunakan masyarakat sebagai wadah untuk interaksi. Hal tersebut dikarenakan, manusia sebagai makhluk sosial membutuhkan interaksi sosial dengan cakupan 
yang cukup luas mulai dari interaksi domestik hingga skala lingkungan (neighbourhood). Anakanak butuh untuk berinteraksi dengan orang tua mereka, demikian juga pasangan suami istri dan sanak saudara mereka. Pengertian yang lebih luas, seseorang juga butuh untuk berinteraksi dengan teman-teman dan membentuk kelompok sosial (Stangor, 2004:3). Menurut Gehl (1987), keberadaan aktivitas pada ruang luar dapat menjadi indikator kualitas ruang publik perkotaan. Secara logis cukup jelas dengan asumsi bahwa aktivitas manusia dilakukan dengan tujuan yang random, orang cenderung akan lebih suka beraktivitas pada ruang luar dengan kualitas yang baik. Selain itu, kualitas dapat diinterpretasikan sesuai komponen atribut ruang publik yang sukses yaitu kenyamanan dan image, akses dan keterhubungan, pemanfaatan dan aktivitas sosial (Carmona et al, 2008)

Kota Malang sebagai kota berpenduduk terbesar kedua setelah kota Surabaya, memiliki kepadatan penduduk mencapai angka $7.735 \mathrm{~km}^{2}$ (Kota Malang Dalam Angka Tahun 2016). Kondisi tersebut menyebabkan penggunaan lahan permukiman di Kota Malang cukup tinggi dan berdampak pada kepadatan yang mencerminkan klasifikasi sebagai sebuah kampung kota. Oleh karena itu perlu dilakukan penelitian untuk melihat bagaimana kualitas ruang publik sehingga didapatkan ruang-ruang yang dimanfaatkan secara maksimal dan minimal oleh masyarakat. Selain itu, perlu diketahui juga bagaimana persepsi pengguna terhadap kualitas ruang tersebut mengacu pada kondisi fisik ruang publik dan pemenuhan kebutuhan aktivitas sosial masyarakat perkotaan walaupun daya dukung lahan yang ada terbatas.

\section{METODE PENELITIAN}

Penilaian terhadap kualitas ruang publik dalam penelitian ini menggunakan Good Public Space Index (GPSI), menurut Vikas Mehta (2007) terdapat 6 (enam) variabel yang digunakan dalam penilaian kualitas ruang publik, diantaranya adalah Intensity of Use (ISU), Intensity os Social Use (ISU), People's Duration of Stay (PDS), Temporal Diversity od Use, Variety os Use,dan Diversity of User dan persepsi pengguna ruang publik. Sedangkan penilaian kualitas berdasarkan persepsi akan dinilai melalui variabel kenyamanan dan image yang terdiri dari keteduhan, kebisingan, fasilitas, tingkat keamanan, kebersihan, fasilitas penerangan, tanaman/vegetasi, penataan fasilitas. Variabel akses dan keterhubungan yang terdiri dari kemudahan dan kemudahan penggunaan serta variabel pemanfaatan dan aktivitas sosial yang terdiri dari intensitas penggunaan

Dalam menilai kualitas ruang publik di permukiman kampung pusat dan pinggiran Kota Malang digunakan metode kuantitatif kualitatif dengan pengumpulan data sekunder dan primer (observasi dan kuesioner). Penyebaran kuesioner dilakukan sesuai dengan jumlah sampel. Sampel yang digunakan adalah sampel minimal Roscoe dalam Uma Sekaran (1992:252) yaitu sebaiknya ukuran sampel diantara 30-500 elemen. Teknis sampling untuk persepsi pengguna ruang dapat dilihat pada skema dibawah ini:

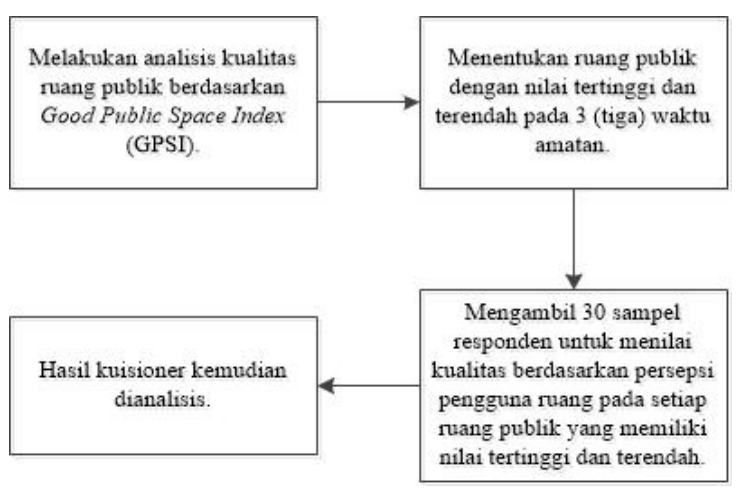

Gambar 1. Skema Sampling untuk Kuisioner

Sebelumnya, kebutuhan data didapatkan dari variabel yang kemudian akan dianalisis. Berikut merupakan variabel yang digunakan dalam penelitian.

\section{Tabel 1. Variabel Penelitian}

\begin{tabular}{|c|c|c|c|}
\hline No. & Tujuan Penelitian & Variabel & Sub Variabel \\
\hline \multirow{4}{*}{1} & \multirow{4}{*}{$\begin{array}{l}\text { Mengidentifikasi } \\
\text { persebaran ruang } \\
\text { publik yang ada di } \\
\text { permukiman } \\
\text { kampung kota pusat } \\
\text { dan pinggiran Kota } \\
\text { Malang. }\end{array}$} & \multirow{4}{*}{$\begin{array}{l}\text { Tipologi } \\
\text { Ruang } \\
\text { Publik }\end{array}$} & Ciri-ciri Fisik \\
\hline & & & Sifat Kepemilikan \\
\hline & & & Fungsi \\
\hline & & & $\begin{array}{l}\text { Kondisi } \\
\text { Pelingkupan }\end{array}$ \\
\hline \multirow{10}{*}{2} & \multirow{10}{*}{$\begin{array}{l}\text { Mengetahui kualitas } \\
\text { ruang publik di } \\
\text { permukiman } \\
\text { kampung pusat dan } \\
\text { pinggiran Kota } \\
\text { Malang. }\end{array}$} & \multirow{6}{*}{$\begin{array}{l}\text { Good } \\
\text { Public } \\
\text { Space } \\
\text { Index } \\
\text { (GPSI) }\end{array}$} & $\begin{array}{l}\text { Intensity of Use } \\
\text { (ISU), }\end{array}$ \\
\hline & & & $\begin{array}{l}\text { Intensity of Social } \\
\text { Use (ISU) }\end{array}$ \\
\hline & & & $\begin{array}{l}\text { People's Duration } \\
\text { of Stay (PDS) }\end{array}$ \\
\hline & & & $\begin{array}{l}\text { Temporal } \\
\text { Diversity of Use }\end{array}$ \\
\hline & & & Variety of Use \\
\hline & & & Diversity of User \\
\hline & & \multirow{4}{*}{$\begin{array}{l}\text { Persepsi } \\
\text { Masyarakat }\end{array}$} & $\begin{array}{l}\text { Kenyamanan dan } \\
\text { Image }\end{array}$ \\
\hline & & & Akses dan \\
\hline & & & Keterhubungan \\
\hline & & & $\begin{array}{l}\text { Pemanfaatan dan } \\
\text { Aktivitas Sosial }\end{array}$ \\
\hline
\end{tabular}

Selanjutnya setelah dilakukan analisis kualitas ruang dengan Good Public Space Index (GPSI) didapatkan ruang publik dengan nilai tertinggi dan terendah berikut ini: 
Tabel 2. Ruang Publik Nilai Tertinggi dan Terendah

\begin{tabular}{|c|c|c|c|c|}
\hline \multicolumn{2}{|l|}{ Lokasi } & $\begin{array}{c}\text { Jenis } \\
\text { Ruang }\end{array}$ & Koding & Sampling \\
\hline \multicolumn{5}{|l|}{ Nilai Tertinggi } \\
\hline \multicolumn{5}{|l|}{ Pusat Kota } \\
\hline \multirow{2}{*}{$\begin{array}{l}\text { Kelurahan } \\
\text { Kota Lama } \\
\text { Kelurahan } \\
\text { Polehan }\end{array}$} & $\begin{array}{c}\text { RW } \\
10\end{array}$ & Ruang & B $1-13$ & $\begin{array}{c}30 \\
\text { Responden }\end{array}$ \\
\hline & $\begin{array}{c}\text { RW } \\
03\end{array}$ & Umum & C $1-14$ & $\begin{array}{c}30 \\
\text { Responden }\end{array}$ \\
\hline $\begin{array}{l}\text { Kelurahan } \\
\text { Kota Lama }\end{array}$ & $\begin{array}{c}\text { RW } \\
10\end{array}$ & $\begin{array}{c}\text { Ruang } \\
\text { Privat } \\
\text { Visibel }\end{array}$ & B $1-2$ & $\begin{array}{c}30 \\
\text { Responden }\end{array}$ \\
\hline \multicolumn{5}{|l|}{$\begin{array}{l}\text { Pinggiran } \\
\text { Kota }\end{array}$} \\
\hline \multirow{3}{*}{$\begin{array}{l}\text { Kelurahan } \\
\text { Tunjungsekar }\end{array}$} & $\begin{array}{c}\text { RW } \\
04\end{array}$ & $\begin{array}{l}\text { Ruang } \\
\text { Umum } \\
\text { Ruang }\end{array}$ & C $2-13$ & $\begin{array}{c}30 \\
\text { Responden }\end{array}$ \\
\hline & RW & $\begin{array}{c}\text { Ruang } \\
\text { Privat } \\
\text { Visibel }\end{array}$ & В $2-3$ & $\begin{array}{c}30 \\
\text { Responden }\end{array}$ \\
\hline & & $\begin{array}{l}\text { Ruang } \\
\text { Umum }\end{array}$ & B $2-4$ & $\begin{array}{c}30 \\
\text { Responden } \\
\end{array}$ \\
\hline \multicolumn{5}{|l|}{$\begin{array}{l}\text { Nilai } \\
\text { Terendah }\end{array}$} \\
\hline \multicolumn{5}{|l|}{ Pusat Kota } \\
\hline \multirow{2}{*}{$\begin{array}{l}\text { Kelurahan } \\
\text { Ciptomulyo }\end{array}$} & RW & Ruang & A $1-23$ & $\begin{array}{c}30 \\
\text { Responden } \\
30\end{array}$ \\
\hline & 03 & Umum & A $1-1$ & $\begin{array}{c}\text { Responden } \\
30 \\
\text { Responden }\end{array}$ \\
\hline \multicolumn{5}{|l|}{$\begin{array}{l}\text { Pinggiran } \\
\text { Kota }\end{array}$} \\
\hline \multirow{3}{*}{$\begin{array}{l}\text { Kelurahan } \\
\text { Tunjungsekar }\end{array}$} & RW & $\begin{array}{l}\text { Ruang } \\
\text { Pilihan }\end{array}$ & B $2-7$ & $\begin{array}{c}30 \\
\text { Responden }\end{array}$ \\
\hline & 02 & Ruang & B $2-15$ & $\begin{array}{c}30 \\
\text { Responden }\end{array}$ \\
\hline & $\begin{array}{c}\text { RW } \\
04\end{array}$ & Umum & C $2-10$ & $\begin{array}{c}30 \\
\text { Responden }\end{array}$ \\
\hline
\end{tabular}

\section{Analisis Tipologi Ruang Publik}

Analisis persebaran ruang publik dalam penelitian ini termasuk ke dalam analisis deskriptif eksploratif. Berikut merupakan skema analisis persebaran ruang publik:

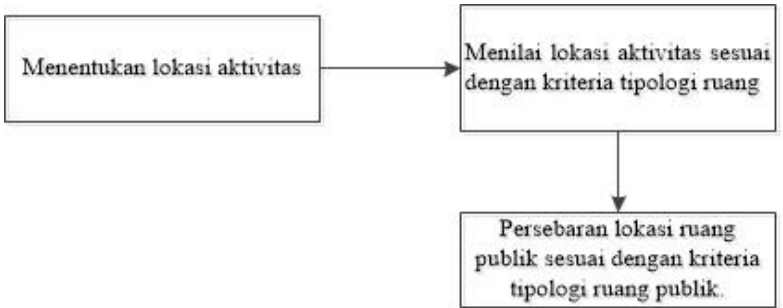

Gambar 5. Skema Analisis Persebaran Ruang Publik

Selain itu, ruang-ruang yang ditemui sebagai lokasi aktivitas masyarakat kemudian akan dinilai sesuai atau tidak dengan kriteria yang ada sehingga ruang tersebut dapat dikelompokkan dalam jenis-jenis ruang publik. Penilaian yang dilakukan sesuai dengan interval per jenis ruang publik.
Tabel 3. Kriteria Tipologi Ruang

\begin{tabular}{|c|c|c|c|c|}
\hline $\begin{array}{c}\text { Tipologi } \\
\text { Ruang }\end{array}$ & $\begin{array}{l}\text { Karakteris } \\
\text { tik } \\
\text { Pembeda }\end{array}$ & Kriteria & $\begin{array}{l}\text { Contoh } \\
\text { Ruang }\end{array}$ & $\begin{array}{c}\text { Interv } \\
\text { al } \\
\text { Penilai } \\
\text { an } \\
\end{array}$ \\
\hline \multicolumn{5}{|c|}{ Ruang Positif } \\
\hline $\begin{array}{l}\text { Ruang } \\
\text { Alami/Se } \\
\text { mi- } \\
\text { Alami }\end{array}$ & $\begin{array}{l}\text { Secara fisik } \\
\text { terbentuk } \\
\text { secara } \\
\text { alami atau } \\
\text { non-alami } \\
\text { dan } \\
\text { biasanya } \\
\text { berada di } \\
\text { bawah } \\
\text { pengelolaan } \\
\text { pemerintah }\end{array}$ & \multirow{2}{*}{$\begin{array}{l}\text { Sifat } \\
\text { Kepemilikan } \\
-\quad \text { Publik } \\
\text { Ciri Fisik } \\
-\quad \text { Alami } \\
-\quad \text { Buatan } \\
\text { Kondisi } \\
\text { Pelingkupan } \\
\text { Ruang } \\
\text { - Pagar } \\
-\quad \text { Tidak } \\
\quad \text { Berpagar }\end{array}$} & $\begin{array}{l}\text { Kawasan } \\
\text { sempadan } \\
\text { sungai, } \\
\text { pantai, } \\
\text { kanal, dan } \\
\text { lain } \\
\text { sebagainya. }\end{array}$ & \multirow{2}{*}{$\begin{array}{l}<3: \\
\text { Tidak } \\
\text { Terma } \\
\text { suk } \\
3-5: \\
\text { Terma } \\
\text { suk }\end{array}$} \\
\hline $\begin{array}{l}\text { Ruang } \\
\text { Umum }\end{array}$ & $\begin{array}{l}\text { Selalu } \\
\text { terbuka dan } \\
\text { tersedia } \\
\text { bagi semua } \\
\text { orang dan } \\
\text { dapat } \\
\text { dipergunak } \\
\text { an untuk } \\
\text { beragam } \\
\text { fungsi }\end{array}$ & & $\begin{array}{l}\text { Jalan } \\
\text { umum, } \\
\text { lapangan, } \\
\text { jalur } \\
\text { [ejalan kaki } \\
\text { (trotoar), } \\
\text { promenade, } \\
\text { dan lain } \\
\text { sebagainya. }\end{array}$ & \\
\hline \multicolumn{5}{|c|}{ Ruang Ambigu } \\
\hline $\begin{array}{l}\text { Ruang } \\
\text { Publik } \\
\text { 'privat' }\end{array}$ & $\begin{array}{l}\text { Biasanya } \\
\text { berupa } \\
\text { ruang yang } \\
\text { seolah-olah } \\
\text { ruang } \\
\text { publik } \\
\text { tetapi } \\
\text { sesungguhn } \\
\text { ya dimiliki } \\
\text { atau } \\
\text { dikelola } \\
\text { secara } \\
\text { privat }\end{array}$ & \begin{tabular}{ll}
\multicolumn{1}{l}{ Sifat } \\
Kepemilikan \\
$-\quad$ Publik \\
$-\quad$ Pribadi/S \\
\multicolumn{2}{c}{ wasta } \\
Ciri Fisik \\
$-\quad$ Alami \\
$-\quad$ Buatan \\
Kondisi \\
Pelingkupan \\
Ruang \\
$-\quad$ Pagar \\
$-\quad$ Tidak \\
\multicolumn{2}{c}{ Berpagar } \\
\end{tabular} & $\begin{array}{l}\text { Taman- } \\
\text { taman dan } \\
\text { trotoar } \\
\text { pada } \\
\text { halaman } \\
\text { pusat } \\
\text { perbelanjaa } \\
\text { n, halaman } \\
\text { rumah } \\
\text { ibadah, dan } \\
\text { lain } \\
\text { sebagainya. }\end{array}$ & $\begin{array}{l}0-3: \\
\text { Tidak } \\
\text { Terma } \\
\text { suk } \\
4-6: \\
\text { Terma } \\
\text { suk }\end{array}$ \\
\hline $\begin{array}{l}\text { Ruang } \\
\text { Privat } \\
\text { Visibel }\end{array}$ & $\begin{array}{l}\text { Berupa } \\
\text { ruang privat } \\
\text { yang } \\
\text { memiliki } \\
\text { akses visual } \\
\text { secara } \\
\text { publik }\end{array}$ & \begin{tabular}{ll}
\multicolumn{1}{l}{ Sifat } \\
Kepemilikan \\
$-\quad$ Publik \\
$-\quad$ Pribadi/S \\
$\quad$ wasta \\
$\quad$ (Diakses \\
$\quad$ publik) \\
- $\quad$ Pribadi \\
Ciri Fisik \\
$-\quad$ Alami \\
$-\quad$ Buatan \\
Kondisi \\
Pelingkupan \\
Ruang \\
$-\quad$ Pagar \\
\end{tabular} & $\begin{array}{l}\text { Halaman } \\
\text { depan } \\
\text { rumah, } \\
\text { lapangan } \\
\text { yang } \\
\text { dilengkapi } \\
\text { pagar, dan } \\
\text { lain } \\
\text { sebagainya. }\end{array}$ & $\begin{array}{l}<3: \\
\text { Tidak } \\
\text { Terma } \\
\text { suk } \\
3-5: \\
\text { Terma } \\
\text { suk }\end{array}$ \\
\hline $\begin{array}{l}\text { Ruang } \\
\text { Pilihan }\end{array}$ & $\begin{array}{l}\text { Berupa } \\
\text { Ruang yang } \\
\text { pemanfaata } \\
\text { nnya dipilih } \\
\text { oleh } \\
\text { kelompok } \\
\text { tertentu } \\
\text { berdasarkan } \\
\text { usia, } \\
\text { aktivitas } \\
\text { dan lain } \\
\text { sebagainya }\end{array}$ & \begin{tabular}{ll} 
Sifat \\
Kepemilikan \\
$-\quad$ Publik \\
$-\quad$ Pribadi \\
Ciri Fisik \\
$-\quad$ Alami \\
$-\quad$ Buatan \\
Kondisi \\
Pelingkupan \\
Ruang \\
$-\quad$ Pagar \\
$-\quad$ Tidak \\
\multicolumn{2}{c}{ Berpagar } \\
\end{tabular} & $\begin{array}{l}\text { Skatepark, } \\
\text { taman } \\
\text { bermain, } \\
\text { dan } \\
\text { lapangan } \\
\text { olahraga, } \\
\text { dan lain } \\
\text { sebagainya. }\end{array}$ & $\begin{array}{l}0-3: \\
\text { Tidak } \\
\text { Terma } \\
\text { suk } \\
4-6: \\
\text { Terma } \\
\text { suk }\end{array}$ \\
\hline
\end{tabular}

\section{Analisis Kualitas Penggunaan Ruang}

\section{1) Good Public Space Index (GPSI)}

Good Public Space Index (GPSI) digunakan untuk mengetahui kualitas penggunaan ruang yang didasarkan pada pola aktivitas masyarakat pada ruang tersebut. Metode ini memiliki beberapa variabel, antara lain: 
a. Intensitas penggunaan, yang diukur dari jumlah orang yang terlibat dalam aktivitas statis dan dinamis pada ruang luar. Rumus yang digunakan yaitu:

$$
I U=\frac{\text { Rata-rata Jumlah Orang }}{\text { Jumlah Tertinggi }}
$$

b. Intensitas aktivitas sosial, yang diukur berdasarkan jumlah orang dalam setiap kelompok yang terlibat dalam aktivitas statis dan dinamis pada ruang luar. Perhitungan interaksi sosial menggunakan rumus dibawah ini.

$$
I S U=\frac{\text { Jumlah Orang dalam Kelompok }}{\text { Jumlah Tertinggi }}
$$

c. Durasi aktivitas, yang diukur berdasarkan berapa lama waktu yang dipergunakan orang untuk beraktivitas pada ruang luar. Rumus untuk menghitung indikator durasi aktivitas adalah:

$P D S=\frac{\text { Rata-rata } \text { waktu }}{\text { Waktu Tertinggi }}$

d. Keanekaragaman penggunaan, yang diukur dengan menghitung penggunaan ruang selama durasi hari. Menggunakan Simpson's Diversity Index dengan melihat penggunaan ruang yang dilakukan oleh beberapa individu selama durasi lain.

$D=\frac{\operatorname{Totaln}(n-1)}{N(N-1)}$

Simpson'sDiversity Index $=1-D$

Keterangan:

$\mathrm{D}=$ Simpson's Index

$\mathrm{n}=$ jumlah aktivitas yang dilakukan

$\mathrm{N}=$ jumlah keseluruhan aktivitas yang dilaksanakan

Kriteria yang digunakan untuk mengetahui keanekaragaman berdasarkan Simpson's Diversity Index tersebut adalah:

- Jika D lebih dari 1 mendekati 1 ( $\mathrm{D} \geq$ 1), maka keanekaragaman rendah dan kelimpahan tinggi

- Jika D kurang dari 1 atau mendekati 1 (D $\leq 1)$, maka keanekaragaman tinggi dan kelimpahan rendah.

e. Variasi penggunaan, yang diukur berdasarkan keberagaman atau jumlah tipologi aktivitas yang dilaksanakan pada ruang luar. f. Keberagaman penggunaan, yang diukur berdasarkan variasi pengguna berdasarkan usia, jenis kelamin, dan lain sebagainya.

Kemudian dalam pelaksanaannya, dari keenam variabel Good Public Space Index (GPSI) dilakukan standarisasi nilai dengan menggunakan rumus sebagai berikut:

Standarised score $=\frac{\text { raw'score }_{\text {maximum 'raw'score }}}{\text { maw }}$
Keterangan:

Standarised Score

'raw' score

Maximum 'raw' score
$=$ standarisasi dari perhitungan variabel

$=$ nilai dari variabel

= nilai maksimum dari variabel
Adapun pembagian kategori nilai yang akan digunakan sebagai dasar interprtasi data untuk kualitas penggunaan ruang publik adalah sebagai berikut:

$$
\begin{array}{ll}
0.00-1.50 & =\text { Tidak Baik } \\
1.51-3.00 & =\text { Cukup Baik } \\
3.01-4.50 & =\text { Baik } \\
4.51-6.0 & =\text { Sangat Baik }
\end{array}
$$

\section{2) Persepsi Pengguna Ruang}

Penjabaran data yang didapatkan dari hasil kuisioner untuk mengetahui kualitas ruang publik beradasrkan persepsi pengguna menggunakan statistika deskriptif. Informasi yang disajikan berupa besaran atau persentase kondisi ruang yang dipilih oleh pengguna ruang publik sebagai responden.

\section{HASIL DAN PEMBAHASAN}

\section{Tipologi Penggunaan Ruang Publik}

Ruang publik yang telah teridentifikasi kemudian di kelompokkan sesuai dengan jenis ruangnya, berikut merupakan contoh ruang publik berdasarkan hasil survey.

Secara keseluruhan, tidak semua ruang publik digunakan pada weekdays, weekend hari sabtu, dan weekend hari minggu. Pada weekdays dan weekend hari sabtu, berdasarkan hasil survey jumlah ruang publik yang digunakan oleh masyarakat permukiman kampung pusat kota sama yaitu sebanyak 43 lokasi, sedangkan pada weekend hari minggu jumlah tersebut meningkat menjadi 59 lokasi. Hal tersebut dikarenakan beberapa faktor salah satunya seperti keberagaman usia pengguna ruang publik, terdapat ruang yang hanya digunakan pada weekend hari sabtu dan hari minggu dikarenakan pengguna ruang yang biasa menggunakan ruang publik tersebut mayoritas memiliki kegiatan 
utama yaitu bekerja sehingga waktu penggunaan ruang publik terbatas.

\section{Tabel 4. Tipologi Ruang Publik Kampung} Pusat Kota
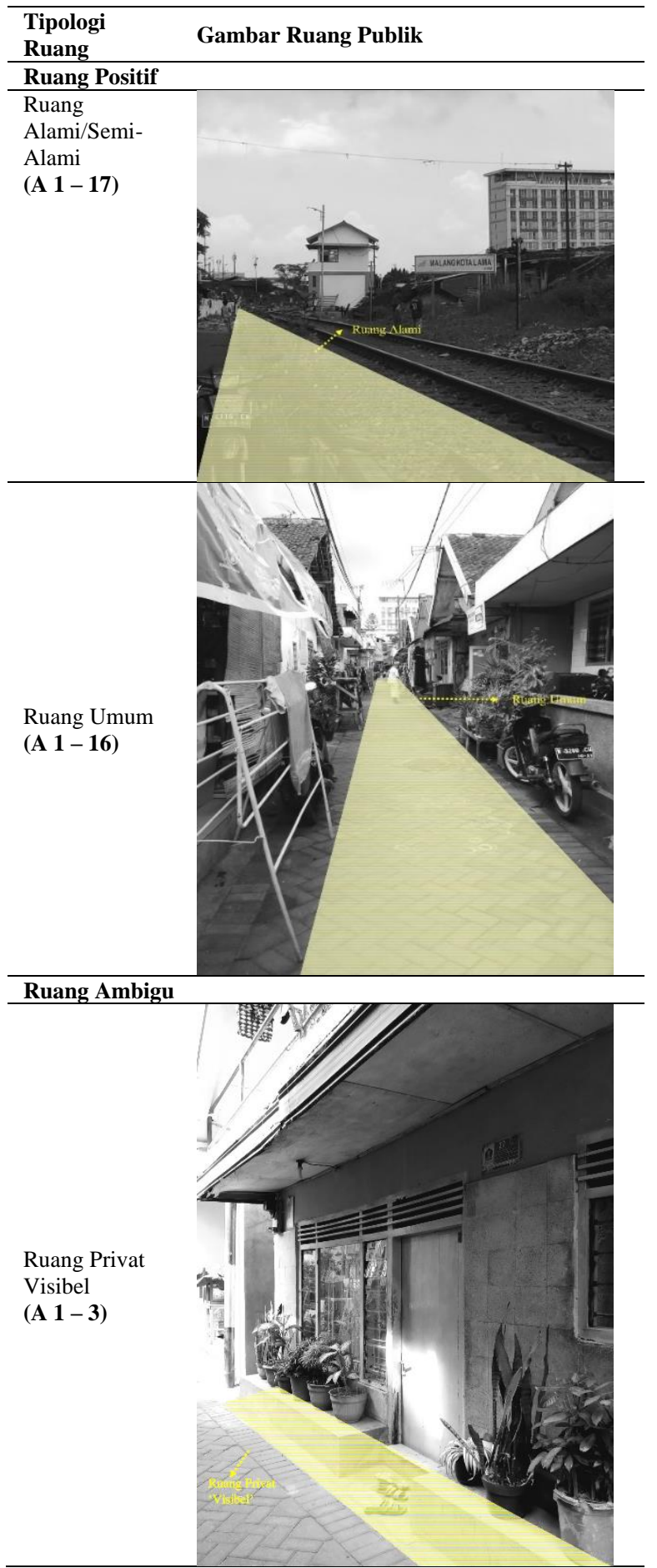

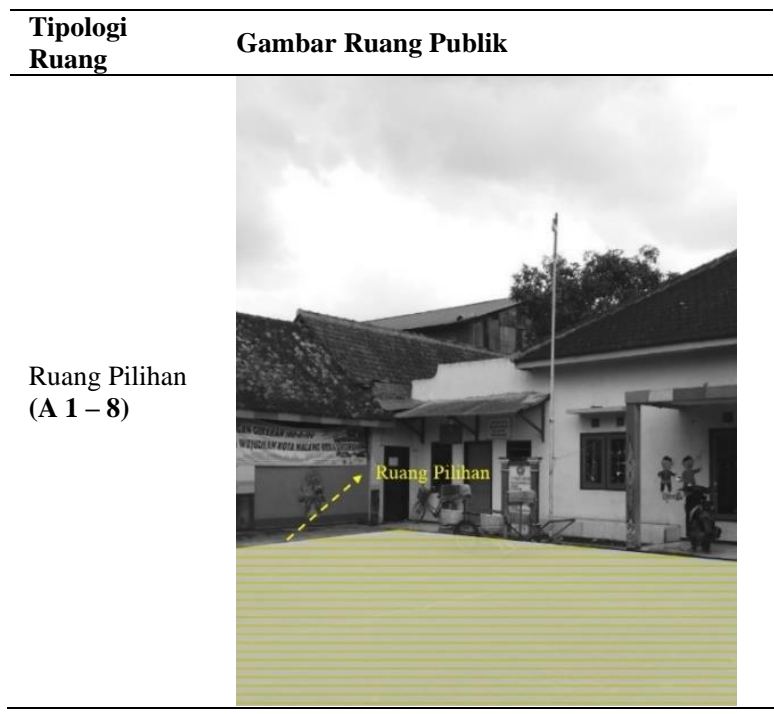

Tabel 5. Tipologi Ruang Publik Kampung Pinggiran Kota

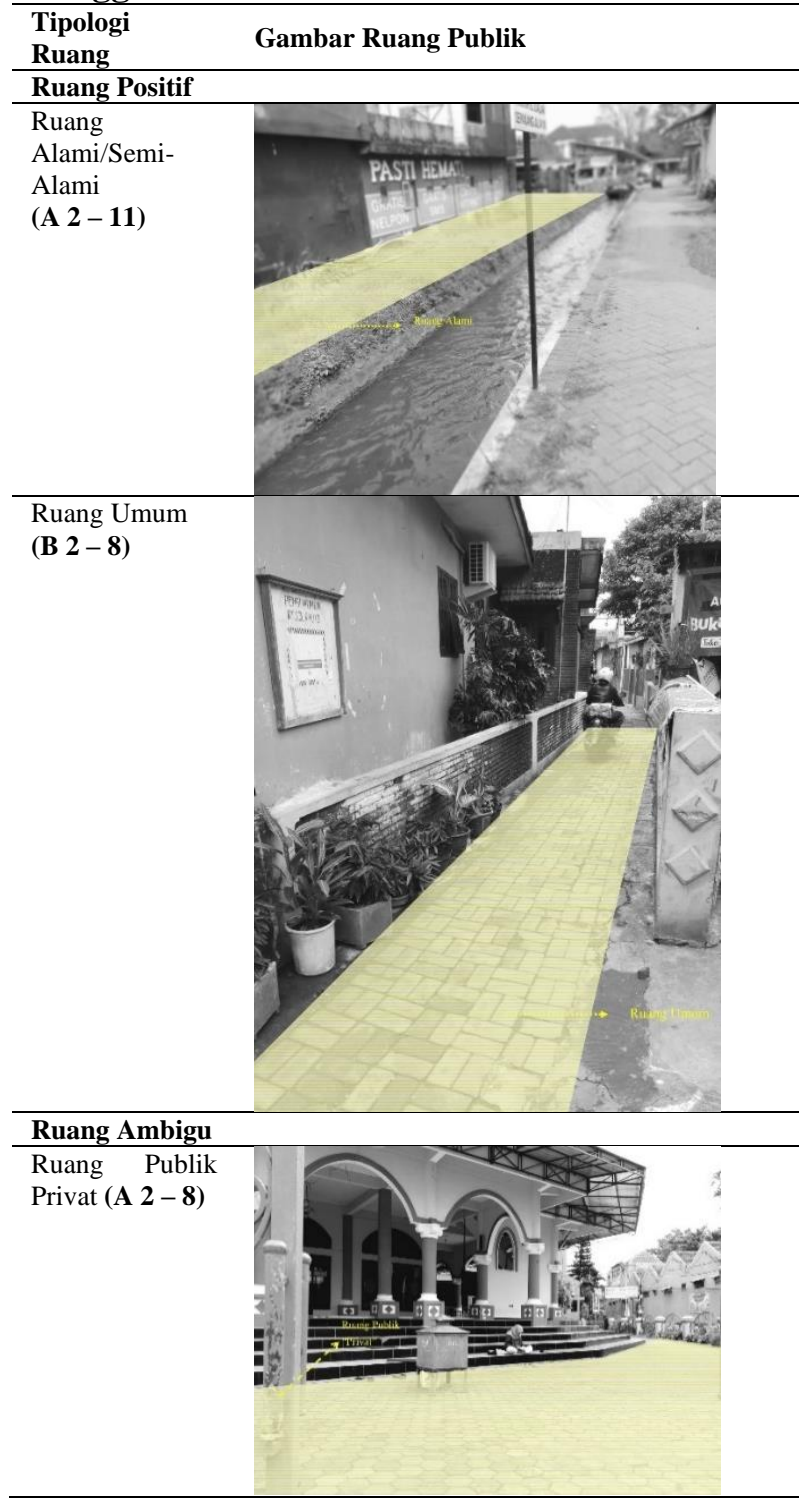




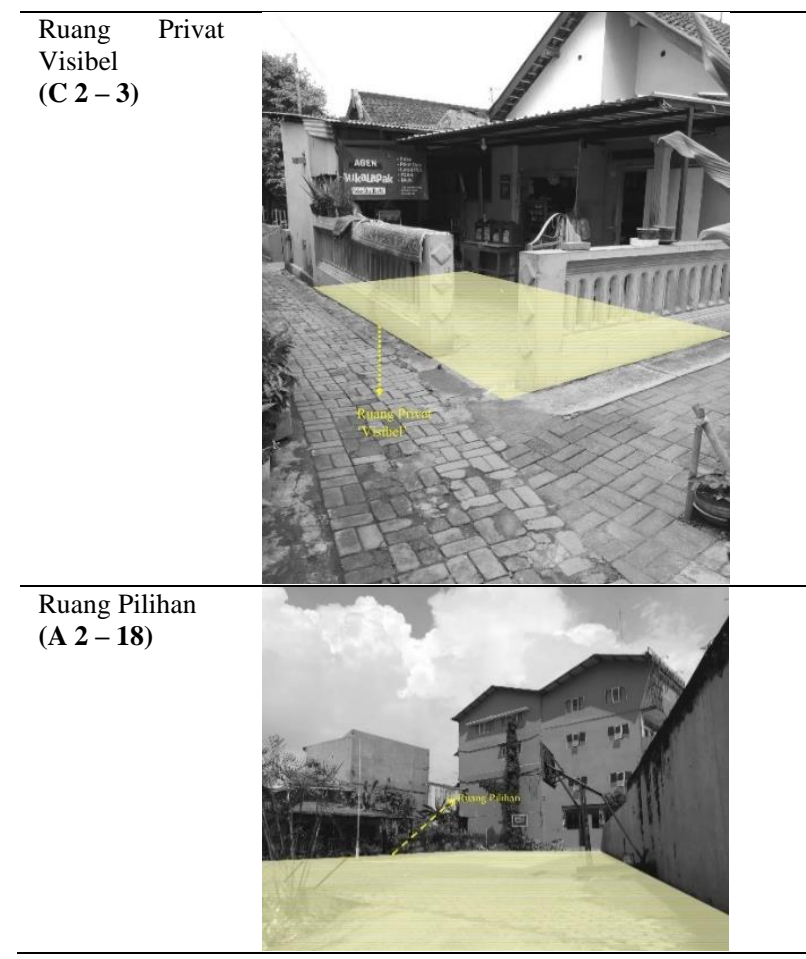

Jumlah terbesar ruang publik yang digunakan oleh masyarakat yaitu pada weekend hari minggu sebanyak 50 lokasi ruang publik. Sama hal nya dengan ruang publik yang ada di permukiman kampung pusat kota, pada ruang publik di permukiman kampung pinggiran kota juga terdapat ruang-ruang yang tidak digunakan pada semua waktu amatan. Berbeda dengan pengguna ruang publik yang ada di permukiman kampung pusat kota, faktor yang melatarbelakangi pengguna ruang di kampung pinggiran kota tidak terlalu beragam. Menurut pengguna ruang publik hal yang membuat mereka selalu melakukan aktivitas di ruang-ruang tersebut karena kebiasaan, sedangkan untuk ruang-ruang yang tidak digunakan pada semua waktu dikarenakan pengguna ruang sadar bahwa fungsi utama dari ruang tersebut bukan untuk aktivitas sehari-hari.

\section{Kualitas Ruang Publik}

Berdasarkan hasil analisis kualitas ruang menggunakan Good Public Space Index (GPSI) dan analisis kualitas ruang berdasarkan persepsi pengguna ruang publik, dapat diketahui bahwa:

Tabel 6. Kualitas Ruang Publik Hasil Penilaian Good Public Space Index (GPSI) dan Hasil Analisis Persepsi Pengguna Ruang

\begin{tabular}{|c|c|c|c|c|}
\hline No. & Ruang Publik & $\begin{array}{c}\text { Kualitas Ruang Publik } \\
\text { (Good Public Space } \\
\text { Index) }\end{array}$ & $\begin{array}{l}\text { Kualitas Ruang Publik } \\
\text { (Persepsi Masyarakat) }\end{array}$ & Keterangan \\
\hline \multicolumn{5}{|c|}{ Nilai Tertinggi } \\
\hline \multicolumn{5}{|c|}{ Pusat Kota } \\
\hline 1 & $\begin{array}{l}\text { Ruang Umum } \\
\text { B } 1-13\end{array}$ & $\begin{array}{c}4.90 \\
-\quad \text { Sangat Baik } \\
\end{array}$ & - $\quad$ Sangat Baik & - \\
\hline 2 & $\begin{array}{l}\text { Ruang Umum } \\
\text { C } 1-14\end{array}$ & $\begin{array}{c}4.86 \\
\text { - } \quad \text { Sangat Baik } \\
\end{array}$ & - $\quad$ Sangat Baik & - \\
\hline 3 & $\begin{array}{l}\text { Ruang Privat Visibel } \\
\text { B } 1-2\end{array}$ & $\begin{array}{c}4.91 \\
-\quad \text { Sangat Baik } \\
\end{array}$ & - $\quad$ Sangat Baik & - \\
\hline \multicolumn{5}{|c|}{ Pinggiran Kota } \\
\hline 4 & $\begin{array}{l}\text { Ruang Umum } \\
\mathrm{C} 2-13\end{array}$ & $\begin{array}{c}4.95 \\
-\quad \text { Sangat Baik } \\
\end{array}$ & Baik & - \\
\hline 5 & $\begin{array}{l}\text { Ruang Privat Visibel } \\
\text { B } 2-3\end{array}$ & $\begin{array}{c}5.10 \\
-\quad \text { Sangat Baik } \\
\end{array}$ & - $\quad$ Sangat Baik & - \\
\hline 6 & $\begin{array}{l}\text { Ruang Umum } \\
\text { B } 2-4\end{array}$ & $\begin{array}{c}4.85 \\
-\quad \text { Sangat Baik } \\
\end{array}$ & - $\quad$ Sangat Baik & - \\
\hline \multicolumn{5}{|c|}{ Nilai Terendah } \\
\hline \multicolumn{5}{|c|}{ Pusat Kota } \\
\hline 1 & $\begin{array}{l}\text { Ruang Umum } \\
\text { A } 1-23\end{array}$ & $\begin{array}{c}1.27 \\
\bullet \quad \text { Tidak Baik }\end{array}$ & - Baik & $\begin{array}{l}\text { Berdasarkan hasil GPSI kualitas ruang publik } \\
\text { tidak baik, sedangkan menurut pengguna } \\
\text { ruang publik kualitas ruang publik baik. } \\
\text { Walaupun kondisi fisik sudah baik, pengguna } \\
\text { ruang tidak bisa melakukan beragam aktivitas } \\
\text { di ruang ini sehingga nilai GPSI terkait } \\
\text { dengan keberagaman aktivitas dan } \\
\text { pelaksanaan aktivitas secara berkelompok } \\
\text { atau individu sangat kecil. Selain itu juga ada } \\
\text { beberapa hal yang membuat pengguna ruang } \\
\text { tidak sering melakukan aktivitas pada ruang } \\
\text { ini. Seperti kondisi ruang yang tidak menarik } \\
\text { dan aktivitas lain, hal tersebut membuat } \\
\text { pengguna ruang jarang melakukan aktivitas } \\
\text { di ruang ini. }\end{array}$ \\
\hline 2 & \multirow{2}{*}{$\begin{array}{l}\text { Ruang Umum } \\
\text { A } 1-1\end{array}$} & $\begin{array}{cc} & 1.38 \\
\bullet \quad & \text { Tidak Baik } \\
\end{array}$ & & \multirow{2}{*}{$\begin{array}{l}\text { Hasil persepsi pengguna ruang terhadap } \\
\text { kualitas ruang publik baik. Tetapi menurut } \\
\text { pengguna ruang tidak ada ketertarikan besar } \\
\text { untuk selalu menggunakan ruang publik ini, }\end{array}$} \\
\hline 3 & & $\begin{array}{c}1.92 \\
-\quad \text { Cukup Baik } \\
\end{array}$ & - Baik & \\
\hline
\end{tabular}




\begin{tabular}{|c|c|c|c|c|}
\hline No. & Ruang Publik & $\begin{array}{c}\text { Kualitas Ruang Publik } \\
\text { (Good Public Space } \\
\text { Index) }\end{array}$ & $\begin{array}{l}\text { Kualitas Ruang Publik } \\
\text { (Persepsi Masyarakat) }\end{array}$ & Keterangan \\
\hline & & & & $\begin{array}{l}\text { selain itu juga ada rasa malas dari pengguna } \\
\text { ruang dalam melakukan aktivitas karena } \\
\text { pernah ada perselisihan dengan tetangga di } \\
\text { ruang publik ini. Oleh karena itu hasil } \\
\text { penilaian kualitas ruang publik berdasarkan } \\
\text { GPSI tidak baik dan cukup baik karena } \\
\text { memang aktivitas yang dilakukan tidak } \\
\text { beragam tetapi masih ditemui pengguna } \\
\text { ruang yang melakukan aktivitas secara } \\
\text { berkelompok. }\end{array}$ \\
\hline
\end{tabular}

\begin{tabular}{|c|c|c|c|c|}
\hline \multicolumn{5}{|c|}{ Pinggiran Kota } \\
\hline 4 & $\begin{array}{l}\text { Ruang Pilihan } \\
\text { B } 2-7\end{array}$ & $\begin{array}{c}2.50 \\
\text { - } \quad \text { Cukup Baik } \\
\end{array}$ & - $\quad$ Tidak Baik & - \\
\hline 5 & $\begin{array}{l}\text { Ruang Umum } \\
\text { B } 2-15\end{array}$ & $\begin{array}{c}1.22 \\
\text { • } \quad \text { Tidak Baik }\end{array}$ & - $\quad$ Baik. & $\begin{array}{l}\text { Hasil GPSI ruang publik ini menunjukkan } \\
\text { bahwa kualitas ruang publik tidak baik dan } \\
\text { hasil kualitas dari pengguna ruang publik } \\
\text { termasuk baik. Kondisi tersebut dikarenakan } \\
\text { adanya kesadaran dari pengguna ruang bahwa } \\
\text { fungsi utama dari ruang tersebut bukanlah } \\
\text { untuk beraktivitas, selain itu juga bising } \\
\text { sehingga hanya digunakan sekali waktu dan } \\
\text { hanya aktivitas tertentu saja yang bisa } \\
\text { dilakukan di ruang publik ini sehingga } \\
\text { mempengaruhi penilaian GPSI terkait dengan } \\
\text { keberagaman aktivitas yang dilakukan. }\end{array}$ \\
\hline 6 & $\begin{array}{l}\text { Ruang Umum } \\
\text { C } 2-10\end{array}$ & $\begin{array}{c}2.25 \\
\text { - } \quad \text { Cukup Baik }\end{array}$ & - Baik & $\begin{array}{l}\text { Menurut pengguna ruang publik kualitas } \\
\text { ruang ini baik, pengguna ruang melakukan } \\
\text { aktivitas pada waktu-waktu tertentu, } \\
\text { beberapa pengguna ruang bahkan pernah } \\
\text { mendapat teguran dari pemilik rumah yang } \\
\text { ada di dekat ruang publik ini sehingga hanya } \\
\text { dapat melakukan aktivitas tertentu, tetapi } \\
\text { aktivitas yang dilakukan dapat } \\
\text { mengakomodir kebutuhan interaksi karena } \\
\text { dilakukan secara berkelompok. }\end{array}$ \\
\hline
\end{tabular}

\begin{tabular}{l}
\hline Klasifikasi: \\
Tidak Baik \\
Cukup Baik \\
Baik \\
Sangat Baik
\end{tabular}

Sumber: Hasil Survey, 2018

\section{KESIMPULAN}

Berdasarkan hasil analisis kualitas penggunaan ruang publik, maka dapat disimpulkan bahwa:

1. Pada kampung pusat kota tidak semua ruang publik selalu digunakan karena pengguna ruang memiliki kesibukan lain seperti bekerja sehingga baru menggunakan ruang pada waktu-waktu tertentu dan ruang publik yang biasa digunakan memiliki fungsi lain pada beberapa waktu seperti digunakan untuk menjemur baju. Sedangkan pada kampung pinggiran kota ruang publik yang hanya digunakan pada beberapa waktu amatan menurut pengguna ruang dikarenakan tidak menarik dan kesadaran bahwa fungsi utama ruang tersebut bukan untuk aktivitas sehari-hari serta tidak ada keharusan untuk melakukan aktivitas setiap waktu pada ruang publik tersebut sehingga pengguna ruang bebas melakukan aktivitas sesuai keinginan.
2. Menurut persepsi pengguna ruang di kampung pusat kota kondisi ruang publik rata-rata sudah baik tetapi belum bisa mengakomodir beragam aktivitas dan interaksi sosial yang dilakukan. Secara umum pengguna ruang publik di kampung pinggiran kota menilai kualitas ruang di kampung pinggiran kota baik, hanya perlu ditingkatkan pada penyediaan fasilitas agar ruang publik menjadi lebih menarik. Pengguna ruang di permukiman kampung pinggiran kota cenderung memiliki kesadaran dimana ruang yang digunakan untuk melakukan aktivitas memiliki fungsi utama bukan sebagai ruang aktivitas masyarakat tetapi lebih kepada ruang untuk mobilisasi.

\section{DAFTAR PUSTAKA}

Badan Pusat Statistik. (2016). Kota Malang dalam Angka Tahun 2016. Malang: Badan Pusat Statistik. 
Badan Pusat Statistik. (2015). Kota Malang dalam Angka Tahun 2015. Malang: Badan Pusat Statistik.

Darmawan, Edy. (2003). Teori dan Kajian Ruang Publik. Semarang: Badan Penerbit Universitas Diponegoro.

Direktorat Jenderal Cipta Karya. (1997). Kamus Tata Ruang, Edisi I, Direktorat Jenderal Cipta Karya Departemen Pekerjaan Umum. Ikatan Ahli Perencanaan Indonesia: Jakarta.

Raisya N. dan Bitta P.(2015). Kajian Karakteristik Kawasan Permukiman Kampung Kumuh di Kampung Kota. Jurnal Teknik PWK Volume 2. Hal 1.
Republik Indonesia. (2007). Undang-undang No. 26 Tahun 2007 tentang Penataan Ruang.

Sekaran, Uma. (1992). Research Methods for Business. Third Edition. Southern Illionis University.

Stangor, C. (2004). Social groups in action and interaction. New York: Psychology Press.

Yusran, Aulia. (2006). Kajian Perubahan Tata Guna Lahan Pada Pusat Kota Cilegon. Semarang: Universitas Diponegoro. 